Utilitarian framings of biodiversity shape environmental impact assessment in development cooperation

Supplementary material

Hugé, Jean; Rochette, Anne-Julie; Janssens de Bisthoven, Luc; Dahdouh-Guebasa, Farid; Koedam, Nico \& VANHOVE, Maarten (2017) Utilitarian framings of biodiversity shape environmental impact assessment in development cooperation. In:

ENVIRONMENTAL SCIENCE \& POLICY, 75, p. 91-102.

DOI: 10.1016/j.envsci.2017.06.003

Handle: http://hdl.handle.net/1942/23865 


\section{Utilitarian framings of biodiversity shape environmental impact assessment in development cooperation}

\section{Tables}

Table 1: Schematic overview of key descriptors of ideal-typical biodiversity framings derived from the scientific literature (adapted from Holmes et al., 2011; Mace, 2014; Miller et al., 2011; Tallis \& Lubchenco, 2014)

\begin{tabular}{|l|l|l|}
\hline Biodiversity framings & Key descriptors & Source \\
\hline Nature for itself & $\begin{array}{l}\text { Species; } \\
\text { Wilderness; } \\
\text { Protected Areas; }\end{array}$ & Mace (2014) \\
\hline Nature despite people & $\begin{array}{l}\text { Extinction threats, threatened species; } \\
\text { Habitat loss; } \\
\text { Pollution; } \\
\text { Overexploitation; }\end{array}$ & Mace (2014) \\
\hline Nature for people & $\begin{array}{l}\text { Ecosystems; } \\
\text { Ecosystem services; } \\
\text { Economic values; }\end{array}$ & Mace (2014) \\
\hline People and nature & $\begin{array}{l}\text { Environmental Change; } \\
\text { Resilience; } \\
\text { Adaptability; } \\
\text { Socio-ecological systems; }\end{array}$ & Mace (2014) \\
\hline Nature protectionists & $\begin{array}{l}\text { Protected Areas (PAs); } \\
\text { Limiting human presence \& disturbance; } \\
\text { Biodiversity protection as primary goal; }\end{array}$ & Miller et al. (2011) \\
\hline
\end{tabular}




\begin{tabular}{|c|c|c|}
\hline Social conservationists & $\begin{array}{l}\text { Sustainable use; } \\
\text { Development and welfare-oriented goals; } \\
\text { Poverty alleviation and social justice; }\end{array}$ & Miller et al. (2011) \\
\hline Traditional conservation 2.0 & $\begin{array}{l}\text { Biocentric motivation; } \\
\text { Conserving ecosystem processes; } \\
\text { Biodiversity in pristine areas and in modified } \\
\text { landscapes; }\end{array}$ & Holmes et al. (2016) \\
\hline Nearly new conservation & $\begin{array}{l}\text { Market-based instruments; } \\
\text { Science should play a strong role; } \\
\text { Avoid harm to people when protecting } \\
\text { biodiversity; }\end{array}$ & Holmes et al. (2016) \\
\hline Market skepticism & $\begin{array}{l}\text { Benefits for people are key; } \\
\text { Opposes links with capitalism and corporations; }\end{array}$ & Holmes et al. (2016) \\
\hline Intrinsic value of nature & Protect nature for its own sake; & Tallis \& Lubchenco (2014) \\
\hline Instrumental value of nature & Protect nature to help ourselves; & Tallis \& Lubchenco (2014) \\
\hline
\end{tabular}

Table 2. Biodiversity-relevant characteristics of the analysed EIAs (Authors Note: Could also be provided as Supplementary Material)

\begin{tabular}{|l|l|l|l|l|}
\hline $\begin{array}{l}\text { EIA Number/ } \\
\text { country }\end{array}$ & $\begin{array}{l}\text { Topic of the project } \\
\text { on which EIA was } \\
\text { applied }\end{array}$ & $\begin{array}{l}\text { Considered biodiversity aspects } \\
\text { in the EIA }\end{array}$ & $\begin{array}{l}\text { Quality and level of detail of } \\
\text { baseline data in the EIA }\end{array}$ & $\begin{array}{l}\text { Use of baseline data in the EIA } \\
\text { environmental management plan } \\
\text { (EMP) }\end{array}$ \\
\hline
\end{tabular}




\begin{tabular}{|c|c|c|c|c|}
\hline EIA 1 / Benin & $\begin{array}{l}\text { Paving of the access } \\
\text { road to a landfill site }\end{array}$ & $\begin{array}{l}\text { - } \\
\text { degative impacts: potential } \\
\text { - Fish 'resources' separated } \\
\text { from other fauna in impact } \\
\text { assessment; } \\
\text { - Temporary increase of water } \\
\text { turbidity could affect fish } \\
\text { resources; }\end{array}$ & $\begin{array}{l}\text { - Vegetation: plantations species } \\
\text { identified; } \\
\text { - } \quad \text { Common birds: species or family } \\
\text { level; } \\
\text { - } \quad \text { General names for fauna } \\
\text { (scavengers, birds, rodents, } \\
\text { insects); } \\
\text { - } \quad \text { Aquatic fauna: species-level; } \\
\text { - Land use map with } 4 \text { vegetation } \\
\text { categories (thickets, plantations, } \\
\text { crops and fallows); }\end{array}$ & 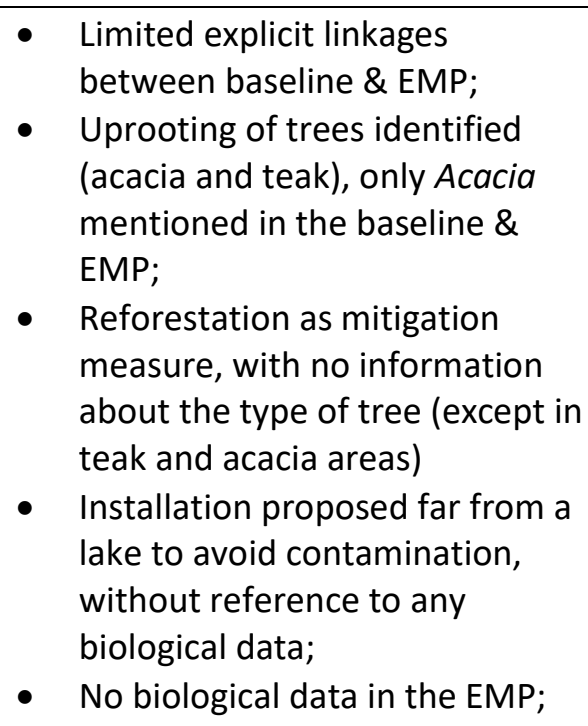 \\
\hline $\begin{array}{l}\text { EIA } 2 \text { / Burkina } \\
\text { Faso }\end{array}$ & $\begin{array}{l}\text { Extension of thermal } \\
\text { power stations }\end{array}$ & $\begin{array}{l}\text { - } \\
\text { regative impacts: plant cover } \\
\text { destruction, fragmentation and } \\
\text { (with no specification); } \\
\text { - Number of trees to be cut } \\
\text { identified (\% of vegetation } \\
\text { cover loss quantified); } \\
\text { - No information about fauna; }\end{array}$ & $\begin{array}{l}\text { - } \quad \text { Ecosystem types cited; } \\
\text { - } \text { Mention of existing (non- } \\
\text { project related) threats to } \\
\text { vegetation; } \\
\text { - } \quad \text { Qualitative presence of some } \\
\text { plant species; } \\
\text { - } \quad \text { Reference to the presence of } \\
\text { plants that are useful for } \\
\text { humans (no specifications); } \\
\text { - No reference to fauna } \\
\text { - } \quad \text { Floristic inventory (as appendix, } \\
\text { not available) includes sanitary } \\
\text { state of trees; } \\
\end{array}$ & $\begin{array}{l}\text { - Reforestation as mitigation } \\
\text { measure, with no information about } \\
\text { the type of tree (only mention that } \\
\text { it will be a mix of local and exotic } \\
\text { species); } \\
\text { - No biological data in the EMP; }\end{array}$ \\
\hline $\begin{array}{l}\text { EIA } 3 \text { / Ivory } \\
\text { Coast }\end{array}$ & $\begin{array}{l}\text { Widening and } \\
\text { asphalting of roads }\end{array}$ & $\begin{array}{l}\text { - Mammals threatened by } \\
\text { poaching, agriculture, } \\
\text { bushfire; }\end{array}$ & $\begin{array}{l}\text { - Qualitative description of } \\
\text { vegetation types, forest }\end{array}$ & $\begin{array}{l}\text { - EMP assumes that there is no } \\
\text { flora or fauna of ecological }\end{array}$ \\
\hline
\end{tabular}




\begin{tabular}{|c|c|c|c|c|}
\hline & & $\begin{array}{l}\text { Plant species impossible to } \\
\text { determine in sacred forests; } \\
\text { - Negative impacts: landscape } \\
\text { alteration and degradation of } \\
\text { plant cover; however: No } \\
\text { significant impact on } \\
\text { biological components as } \\
\text { project in urbanized area; } \\
\text { Vegetation considered for its } \\
\text { role against erosion and } \\
\text { mitigation (replant trees with } \\
\text { deep root systems); }\end{array}$ & $\begin{array}{l}\text { categories and presence of } \\
\text { sacred forests; } \\
\text { - Mention of existing (non- } \\
\text { project related) threats to } \\
\text { mammals in the region: } \\
\text { poaching, agriculture, bushfire; } \\
\text { - Common name of most and } \\
\text { least common mammals and } \\
\text { birds, with reference to } \\
\text { endemism; } \\
\text { - Qualitative presence of groups } \\
\text { ('amphibians', 'insects', } \\
\text { 'reptiles'); } \\
\text { - Mention of domestic animals } \\
\text { presence in the area; }\end{array}$ & $\begin{array}{l}\text { interest in the area (unspecified } \\
\text { in baseline); } \\
\text { - Landscape design often cited in } \\
\text { EMPS, never in the baseline; } \\
\text { - Vegetation monitoring is part of } \\
\text { the EMP; }\end{array}$ \\
\hline $\begin{array}{l}\text { EIA 4 / Ivory } \\
\text { Coast }\end{array}$ & Gas field expansion & $\begin{array}{l}\text { - Reference to the complexity } \\
\text { of marine food chains } \\
\text { - Negative impacts: imbalance } \\
\text { of the marine ecosystem, } \\
\text { habitat disturbance, } \\
\text { contamination, damage to } \\
\text { fish; }\end{array}$ & $\begin{array}{l}\text { Based on field studies: } \\
\text { - } \quad \text { Phytoplankton: (taxa vary from } \\
\text { species-level to class-level, } \\
\text { number/m³) + seasonality } \\
\text { - } \quad \text { Benthic community: trophic } \\
\text { categories, species assemblages, } \\
\text { number of species for each } \\
\text { ecological zone } \\
\text { - Fish: communities (incl. } \\
\text { dominant species), habitat, } \\
\text { seasonality } \\
\text { - Birds: list of important and } \\
\text { migratory species } \\
\text { - Marine mammals + marine } \\
\text { turtles : species, habitat, threats } \\
\text { Ecosystems: forest types with } \\
\text { dominant species; }\end{array}$ & $\begin{array}{l}\text { - Explicit linkages (contamination } \\
\text { risks mentioned in both baseline } \\
\text { and EMP (e.g. mangrove fringes, } \\
\text { coastal lagoons)); } \\
\text { - Monitoring of marine mammals } \\
\text { and marine turtles included in } \\
\text { the EMP; }\end{array}$ \\
\hline
\end{tabular}




\begin{tabular}{|c|c|c|c|c|}
\hline & & & $\begin{array}{l}\text { - Flora: number of woody species, } \\
\text { list of endemic species } \\
\text { - Mammals and reptiles : species- } \\
\text { level } \\
\text { - National parks : description with } \\
\text { important ecosystems/species } \\
\text { - Threatened species }\end{array}$ & \\
\hline $\begin{array}{l}\text { EIA } 5 \text { / Ivory } \\
\text { Coast }\end{array}$ & $\begin{array}{l}\text { Obsolete Pesticides } \\
\text { Management }\end{array}$ & $\begin{array}{l}\text { - Negative impacts : loss of } \\
\text { plant cover, loss of habitats } \\
\text { contamination of fauna and } \\
\text { flora if leaks; } \\
\text { - Microphytes as important } \\
\text { source of primary production } \\
\text { for living matter usable for } \\
\text { humans; } \\
\text { - Floating hydrophytes as } \\
\text { plague; } \\
\text { - Decapods as resource for } \\
\text { fishing and for their role in } \\
\text { the ecosystem; } \\
\text { - Preservation of natural } \\
\text { resources as positive impact } \\
\text { of pesticide decontamination; }\end{array}$ & $\begin{array}{l}\text { - Vegetation: type, area, } \\
\text { pressure, dominant species, } \\
\text { land cover map; } \\
\text { - Qualitative presence of } \\
\text { Macrophytes, phytobenthos, } \\
\text { phyto-and zooplankton, } \\
\text { crustaceans, birds, crocodiles - } \\
\text { macrofauna at various levels } \\
\text { (class to species-level); } \\
\text { - } \text { Quantitative information only } \\
\text { for fish, zooplankton, and extent } \\
\text { of forests and national parks; } \\
\text { - Interactions between species } \\
\text { (crustaceans as food for fish) } \\
\text { - Conservation status and } \\
\text { endemism for a few species; }\end{array}$ & $\begin{array}{l}\text { - } \quad \text { No biological data in EMP; } \\
\text { meforestation as mitigation } \\
\text { plant cover and habitats of high } \\
\text { biodiversity value, with no } \\
\text { information about the type of } \\
\text { tree; }\end{array}$ \\
\hline EIA 6/ Ghana & $\begin{array}{l}\text { Oil field } \\
\text { development }\end{array}$ & $\begin{array}{l}\text { - List of species of fisheries } \\
\text { interest; } \\
\text { Mention of dependencies or } \\
\text { impacts of activities on } \\
\text { ecosystem services (very } \\
\text { detailed); } \\
\text { - Negative impacts: loss \& } \\
\text { fragmentation of habitat, } \\
\text { impacts on flora due to }\end{array}$ & $\begin{array}{l}\text { Very detailed baseline study } \\
\text { based on field surveys with } \\
\text { quantitative data, conservation } \\
\text { status, habitat, seasonality, and } \\
\text { species-level for most taxa, at } \\
\text { project level (areas of influence) } \\
\text { - } 31 \text { ecosystem services identified } \\
\text { for each habitat type; }\end{array}$ & $\begin{array}{l}\text { - Strong linkages between } \\
\text { baseline data \& EMP; } \\
\text { - Monitoring Programs for fish \& } \\
\text { marine turtles included; } \\
\text { - EMP includes sub-plans for } \\
\text { marine fauna, vegetation and } \\
\text { alien species, biodiversity } \\
\text { and ecosystem services; }\end{array}$ \\
\hline
\end{tabular}




\begin{tabular}{|c|c|c|c|c|}
\hline & & $\begin{array}{l}\text { degradation of abiotic } \\
\text { components of } \\
\text { ecosystems, introduction of } \\
\text { alien species, disturbance } \\
\text { and/or displacement of fauna } \\
\text { due to pollution, increased } \\
\text { mortality of wildlife, impacts } \\
\text { on landscape, disturbance of } \\
\text { marine fauna due to physical } \\
\text { disturbance of seabed, etc.; }\end{array}$ & & $\begin{array}{l}\text { Biodiversity management plan } \\
\text { includes: transplantation of } \\
\text { important species, forbidding } \\
\text { collection of specimens, } \\
\text { avoidance, management, } \\
\text { monitoring, repair and } \\
\text { remediate; } \\
\text { - Mitigation options mentioned } \\
\text { for each ecosystem service } \\
\text { affected; }\end{array}$ \\
\hline EIA 7 / Liberia & $\begin{array}{l}\text { Electricity expansion } \\
\text { project }\end{array}$ & $\begin{array}{l}\text { - No reference to a biological } \\
\text { component in impact } \\
\text { assessment; } \\
\text { - Only biodiversity impact } \\
\text { identified: sediment-laden } \\
\text { storm water runoff can } \\
\text { negatively impact aquatic } \\
\text { flora and fauna; }\end{array}$ & $\begin{array}{l}\text { - Qualitative presence of most } \\
\text { common species for flora (9 } \\
\text { cited) and fauna (mammals, } \\
\text { birds, reptiles); } \\
\text { - Conservation status; } \\
\text { - Growth form, dominance and } \\
\text { invasiveness information for } \\
\text { plants; } \\
\text { - National parks and Ramsar } \\
\text { wetlands described at national } \\
\text { level (none in the influence area } \\
\text { of the project); }\end{array}$ & $\begin{array}{l}\text { - No reference to biological data } \\
\text { in the EMP: (quote: 'The pipeline } \\
\text { exists in an industrial area away } \\
\text { from any natural context'); }\end{array}$ \\
\hline EIA 8 / Mali & $\begin{array}{l}\text { Obsolete pesticides } \\
\text { management }\end{array}$ & $\begin{array}{l}\text { - Fauna and flora assessed as } \\
\text { affected environmental } \\
\text { components of 'High' } \\
\text { importance; } \\
\text { - Positive and negative impacts } \\
\text { identified only in general } \\
\text { terms: ('Activities will have a } \\
\text { negative impact on soil, } \\
\text { vegetation') }\end{array}$ & $\begin{array}{l}\text { At national scale: number of } \\
\text { species of mammals, birds and } \\
\text { fish; } \\
\text { - Only for high-risk sites: very } \\
\text { general mention of presence of } \\
\text { domestic animals, flora (e.g. } \\
\text { 'Some bushes and tall grass } \\
\text { surround the site') and fauna } \\
\text { (e.g. 'presence of birds and } \\
\text { rodents') }\end{array}$ & $\begin{array}{l}\text { - Weak link: only reference to } \\
\text { general terms 'fauna 'and } \\
\text { 'vegetation' in EMP; }\end{array}$ \\
\hline
\end{tabular}




\begin{tabular}{|c|c|c|c|c|}
\hline & & $\begin{array}{ll}- & \text { Threats identified on } \\
& \text { biodiversity at national level; }\end{array}$ & & \\
\hline $\begin{array}{l}\text { EIA 9 / } \\
\text { Mauritania }\end{array}$ & $\begin{array}{l}\text { Offshore gas } \\
\text { field } \\
\text { development, } \\
\text { incl. production } \\
\text { wells, subsea } \\
\text { pipeline and } \\
\text { onshore gas } \\
\text { processing } \\
\text { facilities; }\end{array}$ & $\begin{array}{l}\text { Differentiation between local } \\
\text { and regional area of influence } \\
\text { of the project } \\
\text { - Fish data (cf. baseline info) } \\
\text { include information on } \\
\text { fisheries (e.g. fleet, fish } \\
\text { landings); } \\
\text { - Seabed, marine ecology and } \\
\text { terrestrial ecology are } \\
\text { considered; } \\
\text { - Negative impacts: noise } \\
\text { disturbance to marine } \\
\text { mammals; placement of } \\
\text { subsea infrastructure may } \\
\text { lead to impact to seabed and } \\
\text { benthic fauna; occasional oil } \\
\text { spills may cause impact to } \\
\text { marine habitats and species; }\end{array}$ & 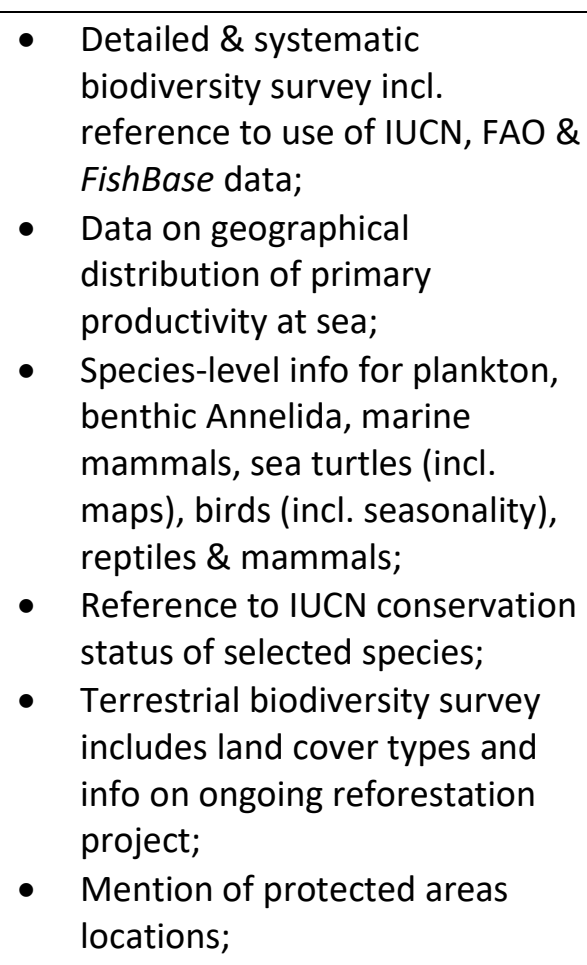 & $\begin{array}{l}\text { - Limited linkage between } \\
\text { baseline and EMP; } \\
\text { - Pre- and post-installation survey } \\
\text { and micro-routing of the } \\
\text { pipeline to avoid sensitive } \\
\text { habitats; } \\
\text { - Careful site layout plus } \\
\text { offsetting of vegetation loss, } \\
\text { based on mapping of vegetation } \\
\text { in baseline study; }\end{array}$ \\
\hline EIA 10 / Niger & $\begin{array}{l}\text { Irrigation project in } \\
\text { arid region }\end{array}$ & $\begin{array}{l}\text { Wild fauna as protein source } \\
\text { (hunting); } \\
\text { - } \quad \text { Fauna as threat to people } \\
\text { (jackals); } \\
\text { - } \quad \text { Negative (vegetation removal) } \\
\text { and positive (regrowth } \\
\text { downstream) impacts of }\end{array}$ & $\begin{array}{l}\text { No quantitative baseline data; } \\
\text { fragmentary qualitative data on } \\
\text { presence of macrofauna } \\
\text { (mammals, birds); } \\
\text { - Species-level data for trees, } \\
\text { including references to national } \\
\text { conservation status; }\end{array}$ & $\begin{array}{l}\text { - } \quad \text { No explicit linkages; } \\
\text { - Hunting ban during construction } \\
\text { phase linked to identified } \\
\text { general poaching threat; }\end{array}$ \\
\hline
\end{tabular}




\begin{tabular}{|c|c|c|c|c|}
\hline & & $\begin{array}{l}\text { irrigation infrastructure } \\
\text { mentioned; }\end{array}$ & $\begin{array}{l}\text { - Mention of existing (non- } \\
\text { project related) threats to fauna } \\
\text { in the region: poaching, } \\
\text { encroachment; }\end{array}$ & \\
\hline $\begin{array}{l}\text { EIA } 11 \text { / } \\
\text { Nigeria }\end{array}$ & $\begin{array}{l}\text { Bridge construction } \\
\text { in National Park }\end{array}$ & $\begin{array}{l}\text { - Soil microorganisms sampled } \\
\text { because of their role in soil } \\
\text { carbon storage; } \\
\text { - } \quad \text { Focus on iconic species: } \\
\text { primates, limited mention of } \\
\text { other mammals and birds; } \\
\text { - Focus on improved national } \\
\text { park management \& } \\
\text { conservation enforcement: } \\
\text { through improved access; } \\
\text { Yet increased accessibility } \\
\text { leads to increased human } \\
\text { movement and hence } \\
\text { increased illegal hunting } \\
\text { cutting \& encroachment by } \\
\text { farmers; }\end{array}$ & $\begin{array}{l}\text { - Fauna studies \& vegetation } \\
\text { studies mentioned, based on } \\
\text { literature review and interviews; } \\
\text { - } \quad \text { Species-level presence data for } \\
\text { primates only, incl. conservation } \\
\text { status; } \\
\text { - } \quad \text { Limited presence list of selected } \\
\text { other taxa (birds, mammals); }\end{array}$ & $\begin{array}{l}\text { - In the EMP: mention of } \\
\text { demarcation between forest } \\
\text { farming and preserved area; } \\
\text { Potential loss of fauna during } \\
\text { construction phase linked to } \\
\text { conservation status of some } \\
\text { species; }\end{array}$ \\
\hline $\begin{array}{l}\text { EIA } 12 \text { / } \\
\text { Nigeria }\end{array}$ & $\begin{array}{l}\text { Building rice } \\
\text { processing centre \& } \\
\text { access roads }\end{array}$ & $\begin{array}{l}\text { Cumulative negative impacts } \\
\text { include: deforestation due to } \\
\text { agricultural development; } \\
\text { - Negative impacts of access } \\
\text { road: biodiversity reduction, } \\
\text { habitat destruction, } \\
\text { impending of wildlife } \\
\text { movement, increase in } \\
\text { poaching and illegal removal } \\
\text { of firewood; }\end{array}$ & $\begin{array}{l}\text { - Qualitative ecosystem } \\
\text { description; } \\
\text { - } \quad \text { List of economically important } \\
\text { crop species; } \\
\text { - Incomplete presence lists of } \\
\text { mammals, birds and reptiles } \\
\text { provided, with qualitative } \\
\text { indications of degree of rarity; }\end{array}$ & $\begin{array}{l}\text { - Set-up of vegetation clearing } \\
\text { and biomass management plan } \\
\text { linked to predicted biodiversity } \\
\text { loss (qualitative); }\end{array}$ \\
\hline
\end{tabular}




\begin{tabular}{|c|c|c|c|c|}
\hline & & $\begin{array}{l}\text { - Eutrophication and } \\
\text { destruction of local ecological } \\
\text { functionalities due to } \\
\text { agriculture; } \\
\text { - Proposal of actions to } \\
\text { decrease demand for } \\
\text { bushmeat; } \\
\text { - Proposed collaboration with } \\
\text { conservation groups; }\end{array}$ & & \\
\hline $\begin{array}{l}\text { ElA 13 / } \\
\text { Nigeria }\end{array}$ & $\begin{array}{l}\text { Power plant \& gas } \\
\text { pipeline }\end{array}$ & $\begin{array}{l}\text { - Basic information on the use } \\
\text { and functions of mangroves } \\
\text { (not site-specific); } \\
\text { - Mention of importance of } \\
\text { ecosystem for local } \\
\text { communities' livelihoods; } \\
\text { - Negative impacts on } \\
\text { freshwater ecology rated very } \\
\text { high as it is a breeding ground } \\
\text { for fish, amphibians etc.; } \\
\text { - Excavation of the pipeline } \\
\text { trench is expected to disperse } \\
\text { sediments which may } \\
\text { smother benthic } \\
\text { invertebrates; } \\
\text { - Heavy metals released } \\
\text { through sediment movement } \\
\text { could bio-accumulate in the } \\
\text { food chain; } \\
\text { - Destruction of bird nests is } \\
\text { expected impact; } \\
\text { - Underwater noise may } \\
\text { disturb marine mammals; }\end{array}$ & $\begin{array}{l}\text { - Info on floristic composition and } \\
\text { forest types, including standard } \\
\text { comment on conservation } \\
\text { status ('there are no unique, } \\
\text { rare or endangered species'); } \\
\text { - Genus-level information } \\
\text { regarding invertebrates; } \\
\text { - Low resolution of baseline data } \\
\text { on e.g. birds where category } \\
\text { such as 'songbirds' is used; }\end{array}$ & $\begin{array}{l}\text { - Link between baseline section } \\
\text { and EMP limited; } \\
\text { Mitigation measures include } \\
\text { adapted drilling technique to } \\
\text { avoid sediment damage; timing } \\
\text { of construction work outside of } \\
\text { main breeding season of birds; } \\
\text { - Use of least intrusive dredging } \\
\text { equipment and dredging during } \\
\text { low tide when feasible, is } \\
\text { advised; }\end{array}$ \\
\hline
\end{tabular}




\begin{tabular}{|c|c|c|c|c|}
\hline & & $\begin{array}{l}\text { - Mitigation includes the } \\
\text { prohibition of hunting \& } \\
\text { selling of bushmeat \& } \\
\text { avoidance of fauna migration } \\
\text { paths; }\end{array}$ & & \\
\hline $\begin{array}{l}\text { EIA } 14 \text { / } \\
\text { Nigeria }\end{array}$ & $\begin{array}{l}\text { Rehabilitation of an } \\
\text { irrigation scheme }\end{array}$ & $\begin{array}{l}\text { - Ponds and game reserves } \\
\text { cited as tourist sites; } \\
\text { - Vegetation in the baseline } \\
\text { study associated to its local } \\
\text { uses; } \\
\text { - Fish as animal protein in } \\
\text { baseline; } \\
\text { - Negative impacts: increased } \\
\text { de-vegetation, and loss of } \\
\text { economically interesting } \\
\text { plants and animals; discharge } \\
\text { of sediment } \\
\text { laden run-off and } \\
\text { contaminants in water runoff } \\
\text { may affect aquatic life; } \\
\text { Biodiversity aspects as a } \\
\text { negative social impact (attack } \\
\text { from dangerous animals } \\
\text { during de-vegetation } \\
\text { activities, increase of crop } \\
\text { production thereby attracting } \\
\text { higher density of pests, } \\
\text { Increased presence of termite } \\
\text { mounds, nematodes, Bat } \\
\text { infestation, Typha grass } \\
\text { invasion, Quelea quela }\end{array}$ & $\begin{array}{l}\text { At state level: } \\
\text { - } \quad \text { Short qualitative description of } \\
\text { vegetation, and number of } \\
\text { domestic animals } \\
\text { - } \quad \text { Sites of significance interest } \\
\text { (tourist places): national parks, } \\
\text { ponds } \\
\text { - } \quad \text { Ecological problems include } \\
\text { desertification, and } \\
\text { environmental degradation (fuel } \\
\text { wood); } \\
\text { At project level: } \\
\text { - Species lists based on field } \\
\text { survey for plant species, } \\
\text { - aquatic plant species, fauna } \\
\text { (only some mammals, birds, } \\
\text { bats, termites, fishes) } \\
\text { - Information on local uses of } \\
\text { plant species } \\
\text { Quantitative data on } \\
\text { increase/decrease of fish catch } \\
\text { (\%) } \\
\text { - Qualitative summary of habitats } \\
\text { types } \\
\text { Damages caused by termites }\end{array}$ & $\begin{array}{l}\text { - } \text { No explicit linkage between } \\
\text { baseline section and EMP; } \\
\text { - Revegetation of cleared areas } \\
\text { planned with beneficial } \\
\text { local species known to } \\
\text { mitigate against erosion } \\
\text { - Clearing should avoid areas with } \\
\text { indigenous vegetation } \\
\text { - Training against attack from } \\
\text { dangerous animals during de- } \\
\text { vegetation activities as } \\
\text { mitigation: } \\
\text { - Anti-birds sprays, insecticides, } \\
\text { rodenticides and physical } \\
\text { disturbance of bats and birds as } \\
\text { mitigation; }\end{array}$ \\
\hline
\end{tabular}




\begin{tabular}{|c|c|c|c|c|}
\hline & & $\begin{array}{l}\text { invasion, grasshoppers } \\
\text { invasion); }\end{array}$ & & \\
\hline $\begin{array}{l}\text { EIA 15 / } \\
\text { Nigeria }\end{array}$ & $\begin{array}{l}\text { - } \begin{array}{l}\text { Gas turbine } \\
\text { power plant }\end{array}\end{array}$ & $\begin{array}{l}\text { Minor negative impacts: } \\
\text { disturbance \& loss of wildlife } \\
\text { considered minor; } \\
\text { - Moderate negative impact: } \\
\text { loss of vegetation \& } \\
\text { disturbance and loss of } \\
\text { benthic organisms t; } \\
\text { - Prohibit hunting \& selling of } \\
\text { bushmeat, train in fauna } \\
\text { avoidance \& migration paths } \\
\text { In mitigation section: restore } \\
\text { \& revegetate, control invasive } \\
\text { plants, design access roads to } \\
\text { minimize destruction and } \\
\text { fragmentation }\end{array}$ & $\begin{array}{l}\text { - Vegetation \& wildlife \& marine } \\
\text { ecology (plankton, benthic } \\
\text { macroinvertebrates, fisheries); } \\
\text { - Details on p. } 19 \text { (habitats \& } \\
\text { vegetation) with focus on plants } \\
\text { with edible fruits; } \\
\text { - Species-level presence info on } \\
\text { limited list of } 35 \text { animals based } \\
\text { on interviews, tracks \& fecal } \\
\text { analysis; } \\
\text { - Species-level info on plankton \& } \\
\text { fish, both in wet and dry season; } \\
\text { - Vegetation survey, incl. } \\
\text { vegetation type and distribution } \\
\text { map; } \\
\text { - Species-level flora info, } \\
\text { including use; } \\
\text { Conservation status listed for } \\
\text { selected mammal species; }\end{array}$ & $\begin{array}{l}\text { - Limited linkages between } \\
\text { baseline data \& EMP; } \\
\text { - Habitat disturbance estimate is } \\
\text { provided (\% of area disturbed } \\
\text { per vegetation type \& location) } \\
\text { in the EMP; }\end{array}$ \\
\hline $\begin{array}{l}\text { EIA 16 / } \\
\text { Nigeria }\end{array}$ & $\begin{array}{l}\text { Urban water supply } \\
\& \text { sanitation project }\end{array}$ & $\begin{array}{l}\text { - Focus on domestic species } \\
\text { only; } \\
\text { - Soil \& water analysis is } \\
\text { detailed; } \\
\text { - Biodiversity defined as } \\
\text { 'terrestrial habitats' in the } \\
\text { impact matrix; } \\
\text { - Mention of increasing human } \\
\text { population that may lead to } \\
\text { biodiversity loss; }\end{array}$ & $\begin{array}{l}\text { - Vegetation assessment done } \\
\text { only on cultivated fields (as the } \\
\text { site is heavily urbanized); } \\
\text { - Species-level fauna info limited: } \\
\text { presence list of domestic } \\
\text { animals and crops; }\end{array}$ & $\begin{array}{l}\text { - No explicit linkages between } \\
\text { baseline data \& EMP; }\end{array}$ \\
\hline
\end{tabular}




\begin{tabular}{|c|c|c|c|c|}
\hline $\begin{array}{l}\text { EIA } 17 \text { / } \\
\text { Senegal }\end{array}$ & $\begin{array}{l}\text { Road rehabilitation } \\
\text { project }\end{array}$ & 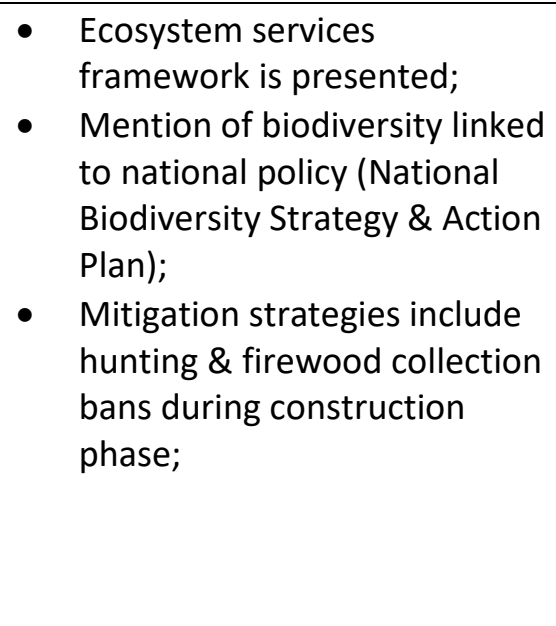 & $\begin{array}{l}\text { - Indicative number of plant } \\
\text { and bird species, compared } \\
\text { to nationally present species } \\
\text { totals; } \\
\text { - Species-level presence info } \\
\text { for four mammals; } \\
\text { - Species-level presence info } \\
\text { for vegetation, including } \\
\text { conservation status } \\
\text { according to National } \\
\text { Forestry Law; } \\
\text { Mention of nearby Marine } \\
\text { Protected Area (MPA); }\end{array}$ & $\begin{array}{l}\text { - No explicit linkages between } \\
\text { baseline data \& EMP, although } \\
\text { mention of avoiding vegetation } \\
\text { loss; }\end{array}$ \\
\hline $\begin{array}{l}\text { EIA 18 / } \\
\text { Senegal }\end{array}$ & $\begin{array}{l}\text { Development of } \\
\text { sewage system }\end{array}$ & $\begin{array}{l}\text { Biodiversity mentions linked } \\
\text { to National Biodiversity } \\
\text { Action Plan and to National } \\
\text { Environmental Law; } \\
\text { Differentiated impacts with or } \\
\text { without mitigation plans } \\
\text { ('variance analysis') on fauna } \\
\text { described; } \\
\text { Flora: negative impact on } \\
\text { photosynthesis due to dust during } \\
\text { construction work; } \\
\text { Impacts of the emission of } \\
\text { wastewater in the lagoon is } \\
\text { considered problematic for two } \\
\text { reasons: crustacean populations } \\
\text { (including nursery function of } \\
\text { mangroves) \& bathing water will } \\
\text { be impacted }\end{array}$ & $\begin{array}{l}\text { - Species \& genus-level presence } \\
\text { data for Mollusca; } \\
\text { - Species-level presence data for } \\
\text { mangrove trees; } \\
\text { - Vernacular names only for birds; } \\
\text { - Focus on MPAs information; }\end{array}$ & $\begin{array}{l}\text { - Based on the biodiversity in the } \\
\text { lagoon, abandoning the } \\
\text { emission of wastewater in } \\
\text { lagoon is proposed; } \\
\text { - Mitigation actions for the } \\
\text { prevention of pollution of the } \\
\text { marine protected area are } \\
\text { listed; }\end{array}$ \\
\hline
\end{tabular}


Table 3. Consideration of biodiversity in the assessed EIAs along three dimensions of the conceptual framework outlined in Section 2. Table 3 is an interpretative synthesis of Table 2. Framings terminology is based on Holmes et al. (2016), Mace (2014), Miller et al. (2011), Tallis \& Lubchenco (2014) as outlined in Table 1. Regarding decision-making context: the symbols refer to the links between the baseline data and the environmental management plan ('-': no link; '+': link; '++': strong link)

\begin{tabular}{|c|c|c|c|}
\hline $\begin{array}{l}\text { EIA } \\
\text { number }\end{array}$ & Biodiversity framing & $\begin{array}{l}\text { Representation of } \\
\text { biodiversity }\end{array}$ & $\begin{array}{l}\text { Decision-making } \\
\text { context }\end{array}$ \\
\hline EIA 1 & $\begin{array}{l}\text { - Intrinsic value / Nature for } \\
\text { itself: species; } \\
\\
\text { - Instrumental Value / Nature for } \\
\text { people / Social conservationist: } \\
\text { ecosystem services (sacred } \\
\text { forest, fish resources separated } \\
\text { from fauna in impact } \\
\text { identification); }\end{array}$ & $\begin{array}{l}\text { Qualitative presence } \\
\text { data } \\
\text { - Species-level (only for } \\
\text { plantations, fishes, } \\
\text { crustaceans, molluscs, } \\
\text { birds) }\end{array}$ & + \\
\hline EIA 2 & $\begin{array}{l}\text { - Intrinsic Value / Nature for } \\
\text { itself: species, habitats); } \\
\text { - Nature despite people / Nature } \\
\text { protectionist / Traditional } \\
\text { Conservation: habitat loss and } \\
\text { overexploitation (threats on } \\
\text { plants: agriculture, livestock, } \\
\text { timber, firewood) } \\
\text { - Nature for people / Nearly New } \\
\text { Conservation / Instrumental } \\
\text { Value: ecosystem services } \\
\text { (plants useful for humans) }\end{array}$ & $\begin{array}{l}\text { - Species-level for some } \\
\text { plants } \\
\text { - Type of ecosystems } \\
\text { present }\end{array}$ & - \\
\hline
\end{tabular}




\begin{tabular}{|c|c|c|c|}
\hline EIA 3 & $\begin{array}{l}\text { - Intrinsic Value / Nature for } \\
\text { itself: species } \\
\text { - Nature despite people / Nature } \\
\text { protectionist: habitat loss and } \\
\text { overexploitation (threats on } \\
\text { mammals: agriculture, } \\
\text { bushfire, poaching) } \\
\text { - Nature for people / } \\
\text { Instrumental Value: ecosystem } \\
\text { services (domestic species, } \\
\text { sacred forests, plant cover } \\
\text { against soil erosion) }\end{array}$ & 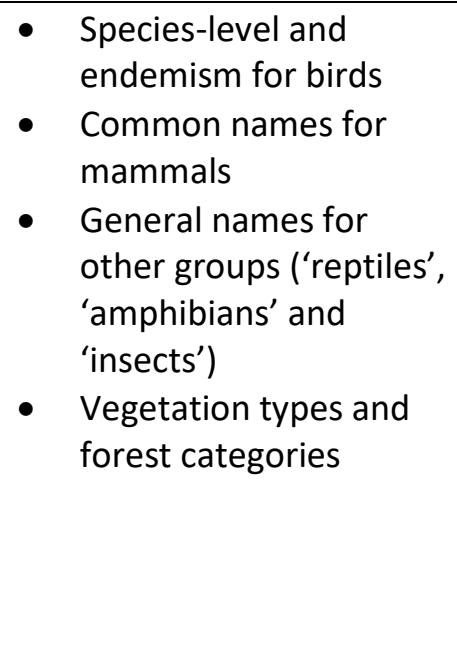 & - \\
\hline EIA 4 & $\begin{array}{l}\text { - Nature for itself / Intrinsic } \\
\text { Value: species, protected areas } \\
\text { (habitats, ecology) } \\
\text { - Instrumental Value / Nature for } \\
\text { people: ecosystems } \\
\text { - Nature protectionist / Nature } \\
\text { despite people: } \\
\text { overexploitation (threats on } \\
\text { marine turtles) }\end{array}$ & $\begin{array}{ll}\text { - } & \text { Species-level } \\
\text { - } & \text { Quantitative data for } \\
& \text { plankton, benthos, } \\
& \text { flora } \\
\text { - } & \text { Habitat information } \\
\text { - } & \text { Seasonality included } \\
\text { - } & \text { Conservation status } \\
\text { - } & \text { Endemism information } \\
\text { - } & \text { Interactions between } \\
& \text { species (food chain) }\end{array}$ & ++ \\
\hline EIA 5 & $\begin{array}{l}\text { - Intrinsic value / Nature for } \\
\text { itself: species, protected areas } \\
\text { - Nature protectionist / Nature } \\
\text { despite people: }\end{array}$ & 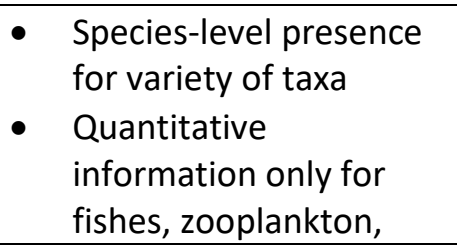 & - \\
\hline
\end{tabular}




\begin{tabular}{|c|c|c|c|}
\hline & $\begin{array}{l}\text { overexploitation and habitat } \\
\text { loss (agriculture, bushfire, } \\
\text { hunt) } \\
\text { - Instrumental Value / Nature for } \\
\text { people / Nearly New } \\
\text { Conservation: ecosystem } \\
\text { services (food resource, } \\
\text { photosynthesis); }\end{array}$ & $\begin{array}{l}\text { and extent of forests } \\
\text { and national parks } \\
\text { - Conservation status and } \\
\text { endemism (qualitative) }\end{array}$ & \\
\hline EIA 6 & $\begin{array}{l}\text { - Nature for itself / Intrinsic } \\
\text { Value: species, protected areas } \\
\text { - Nature protectionist / Nature } \\
\text { despite people: threats, } \\
\text { threatened species, habitat } \\
\text { loss, pollution and } \\
\text { overexploitation } \\
\text { - Instrumental Value / Nature for } \\
\text { people: ecosystems, ecosystem } \\
\text { services (considered as } \\
\text { receptor of impact and } \\
\text { included in EMP) }\end{array}$ & $\begin{array}{ll}\text { - } & \text { Species-level } \\
\text { - } & \text { Conservation status } \\
\text { - } & \text { Seasonality } \\
\text { - } & \text { Migration information } \\
\text { - } & \text { Quantitative data for } \\
& \text { all taxa } \\
\text { - } & \text { Species of fisheries } \\
& \text { interest } \\
\text { - } & \text { Ecosystem services (31) } \\
& \text { for each habitat }\end{array}$ & ++ \\
\hline EIA 7 & $\begin{array}{l}\text { Intrinsic Value / Nature for } \\
\text { itself: species, protected areas } \\
\\
\text { - Nature protectionist / Nature } \\
\text { despite people: threats, } \\
\text { threatened species, pollution, } \\
\text { overexploitation (mining, } \\
\text { firewood, charcoal, fishing) }\end{array}$ & $\begin{array}{ll}\text { - } & \text { Qualitative presence } \\
\text { data } \\
\text { - Species-level } \\
\text { - } \quad \text { Conservation status } \\
\text { - Endemism of plants }\end{array}$ & - \\
\hline
\end{tabular}




\begin{tabular}{|c|c|c|c|}
\hline EIA 8 & $\begin{array}{l}\text { - Intrinsic Value / Nature for } \\
\text { itself: species, protected areas } \\
\text { - Nature protectionist / Nature } \\
\text { despite people: habitat loss and } \\
\text { overexploitation (logging, } \\
\text { overgrazing, poaching, fishing, } \\
\text { bushfire, chemicals, climate } \\
\text { change), pollution (chemicals } \\
\text { for pest control) } \\
\text { - Nature for the } \\
\text { people/Instrumental value: } \\
\text { ecosystem services (domestic } \\
\text { animals and crops) }\end{array}$ & $\begin{array}{l}\text { General descriptors } \\
\text { used ('trees, bushes, } \\
\text { birds') } \\
\text { Number of species of } \\
\text { mammals, birds and } \\
\text { fishes (national scale } \\
\text { only) }\end{array}$ & - \\
\hline EIA 9 & $\begin{array}{l}\text { - Nature protectionist / Nature } \\
\text { despite people: } \\
\text { overexploitation (hunting), } \\
\text { habitat loss (vegetation loss, } \\
\text { fragmentation) } \\
\text { - Instrumental value / Nature for } \\
\text { the people: ecosystem services } \\
\text { (edible fruit crops) }\end{array}$ & $\begin{array}{ll}\text { - } & \text { Ecosystems } \\
\text { information (marine) } \\
\text { - } & \text { Species level data for } \\
\text { plankton, fish, birds, } \\
\text { mammals } \\
\text { - } \quad \text { Seasonality included } \\
\text { - } & \text { Conservation status }\end{array}$ & + \\
\hline EIA 10 & $\begin{array}{l}\text { - Nature protectionist / Nature } \\
\text { despite people: } \\
\text { overexploitation (poaching), } \\
\text { habitat loss (encroachment); } \\
\text { - Instrumental Value / Nature for } \\
\text { the people: ecosystem services } \\
\text { (protein source); }\end{array}$ & $\begin{array}{l}\text { - Qualitative presence } \\
\text { data } \\
\text { - Species-level info only } \\
\text { for trees } \\
\text { - } \quad \text { Conservation status }\end{array}$ & - \\
\hline
\end{tabular}




\begin{tabular}{|c|c|c|c|}
\hline EIA 11 & $\begin{array}{l}\text { - Nature Protectionist / Nature } \\
\text { for itself: protected area } \\
\text { (national park conservation } \\
\text { enforcement) } \\
\text { - Nature protectionist / Nature } \\
\text { despite people: } \\
\text { overexploitation (poaching), } \\
\text { habitat loss (encroachment) } \\
\text { - Instrumental value / Nature for } \\
\text { the people: ecosystem services } \\
\text { (carbon storage) }\end{array}$ & $\begin{array}{l}\text { - } \quad \text { Species level presence } \\
\text { data for primates } \\
\text { - } \quad \text { Conservation status }\end{array}$ & + \\
\hline EIA 12 & $\begin{array}{l}\text { Nature protectionist / Nature } \\
\text { despite people: threats } \\
\text { (wildlife), habitat loss \& } \\
\text { overexploitation } \\
\text { - Instrumental value / Nature for } \\
\text { the people: ecosystem services } \\
\text { (economically important crops) }\end{array}$ & $\begin{array}{ll}\text { - } & \text { Ecosystems } \\
\text { information } \\
\text { - } \\
\text { Qualitative data on } \\
\text { mammals, birds, } \\
\text { reptiles } \\
\text { - } \\
\text { Conservation status } \\
\text { (qualitative) }\end{array}$ & + \\
\hline EIA 13 & $\begin{array}{l}\text { - Intrinsic value / Nature for } \\
\text { itself: protected areas, species } \\
\text { - Social conservationists / People } \\
\text { and nature: socio-ecological } \\
\text { interactions (food chain bio- } \\
\text { accumulation) }\end{array}$ & $\begin{array}{ll}\text { - } & \text { Ecosystems } \\
\text { information } \\
\text { - } & \text { Genus-level data on } \\
\text { invertebrates } \\
\text { - } \quad \text { General descriptions } \\
\text { birds } \\
\text { - Conservation status }\end{array}$ & + \\
\hline EIA 14 & $\begin{array}{l}\text { - Intrinsic Value / Nature for } \\
\text { itself: species, habitats }\end{array}$ & $\begin{array}{l}\text { Species-level for } \\
\text { plant species, } \\
\text { aquatic plant }\end{array}$ & + \\
\hline
\end{tabular}




\begin{tabular}{|c|c|c|c|}
\hline & $\begin{array}{l}\text { Nature protectionist / Nature } \\
\text { despite people: } \\
\text { overexploitation, pollution, } \\
\text { habitat loss } \\
\text { Instrumental value / Nature for } \\
\text { people / Social } \\
\text { conservationists: ecosystem } \\
\text { services (protection against } \\
\text { erosion, food, tourism) }\end{array}$ & $\begin{array}{l}\text { species, fauna } \\
\text { (only some } \\
\text { mammals, birds, } \\
\text { bats, termites, } \\
\text { fishes) } \\
\text { - } \quad \text { Local uses of plant } \\
\text { species } \\
\text { - Quantitative data } \\
\text { on trends in fish } \\
\text { catch } \\
\text { - Qualitative } \\
\text { summary of } \\
\text { habitats types } \\
\end{array}$ & \\
\hline EIA 15 & $\begin{array}{l}\text { Intrinsic value / Nature for } \\
\text { itself: species, protected areas } \\
\text { - Instrumental Value / Nature for } \\
\text { the people: ecosystem services } \\
\text { (fisheries) }\end{array}$ & $\begin{array}{ll}\text { - } & \text { Ecosystems } \\
\text { information (marine \& } \\
\text { terrestrial) } \\
\text { - } \quad \text { Extensive referencing } \\
\text { to biodiversity } \\
\text { databases } \\
\text { - } \quad \text { Species level data for } \\
\text { variety of taxa } \\
\text { - } \quad \text { Conservation status }\end{array}$ & + \\
\hline EIA 16 & $\begin{array}{l}\text { Intrinsic Value / Nature for } \\
\text { itself: species, protected areas } \\
\text { - Instrumental Value / Nature for } \\
\text { the people: ecosystem services } \\
\text { (fisheries) }\end{array}$ & $\begin{array}{ll}\text { - } & \text { Ecosystems } \\
\text { information (marine \& } \\
\text { terrestrial) } \\
\text { - } \\
\text { Extensive referencing } \\
\text { to biodiversity } \\
\text { databases } \\
\text { - } \\
\text { Species level data for } \\
\text { variety of taxa } \\
\text { - Conservation status }\end{array}$ & - \\
\hline
\end{tabular}




\begin{tabular}{|c|c|c|c|}
\hline EIA 17 & $\begin{array}{l}\text { - Instrumental value / Social } \\
\text { Conservationists / Nature for } \\
\text { the people: ecosystem services } \\
\text { (framework presented as } \\
\text { guide) }\end{array}$ & $\begin{array}{ll}\text { - } & \text { Species level data for } \\
& \text { selected taxa }\end{array}$ & - \\
\hline EIA 18 & $\begin{array}{l}\text { - Nature protectionist / Nature } \\
\text { despite people / Traditional } \\
\text { conservation: overexploitation, } \\
\text { pollution, habitat loss } \\
\text { - Intrinsic Value / Nature for } \\
\text { itself: species, protected areas } \\
\text { - Instrumental Value / Nature for } \\
\text { the people: ecosystem services } \\
\text { (food, clean water, recreation) }\end{array}$ & 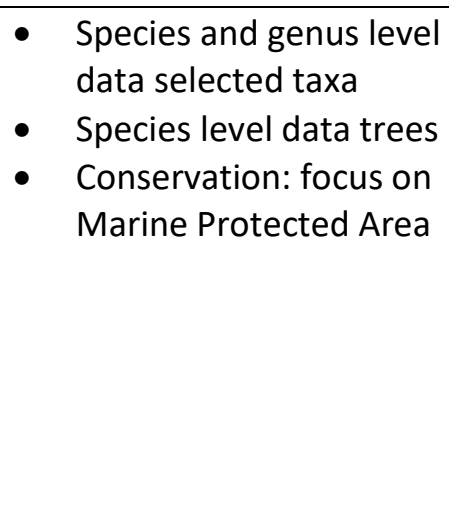 & + \\
\hline
\end{tabular}

